\title{
Effect of different preparation techniques of red dragon fruit (Hylocereus polyrhizus) extracts on normal human fibroblast viability
}

\author{
Novi Febrianti ${ }^{1,2}$,Triana Hertiani ${ }^{3}$, Sukarti Moeljopawiro ${ }^{4}$, \\ Sofia Mubarika Haryana ${ }^{* 5}$ \\ ${ }^{I}$ Department of Biotechnology, Graduate School, Universitas Gadjah Mada \\ ${ }^{2}$ Department of Biology Education,Faculty of Teacher Training and Education \\ Universitas Ahmad Dahlan, Yogyakarta \\ ${ }^{3}$ Department of Pharmaceutical Biology, Faculty of Pharmacy, Universitas Gadjah Mada \\ ${ }^{4}$ Department of Biochemistry, Faculty of Biology, Universitas Gadjah Mada \\ ${ }^{5}$ Department of Histology and Cell Biology, Faculty of Medicine, Public Health, and Nursing \\ Universitas Gadjah Mada
}

Submitted: 07-05-2019

Reviewed: 07-05-2019

Accepted: 18-09-2019

\begin{abstract}
Red dragon fruit is one of the popular fruits that have been widely used both for consumption and food coloring. The red dragon fruit peel and flesh contain various antioxidant compounds that can be used as pharmaceutics and nutraceuticals. The objective of this study was to determine the effect of various extract preparations of the peel and the flesh of red dragon fruit on the viability of normal human fibroblasts. Seven conditions of peel and flesh extracts were prepared as follows, i.e. dried peel ethanolic extract, fresh blended peel ethanolic extract, dried flesh, fresh blended flesh ethanolic extract, blended fresh flesh, filtrate of pressed flesh, and pomace of pressed flesh. Each sample preparation was tested for its effect on the viability of normal human fibroblasts using MTT assay. Results showed that dried peel ethanolic extract reduce cell viability. Red dragon fruit flesh extracts caused no significant effect on the fibroblast viability. In conclusion, the fruit flesh extracts are relatively safer to normal cells than the peel extracts. $\mathrm{IC}_{50}$ value of the ethanolic extract of dried peel was $55.38 \pm 3.85 \mu \mathrm{g} / \mathrm{mL}$, while the $\mathrm{IC}_{50}$ value of various types of flesh extract were more than $500 \mu \mathrm{g} / \mathrm{mL}$.
\end{abstract}

Keywords: red dragon fruit, preparation treatment, fibroblast, viability

\footnotetext{
*Corresponding author:

Sofia Mubarika Haryana

Department of Histology and Cell Biology, Faculty of Medicine, Public Health, and Nursing

Universitas Gadjah Mada

Email:sofia.mubarika@gmail.com
} 


\section{INTRODUCTION}

Red dragon fruit (Hylocereus polyrhizus) is one of the popular fruits that grow in the tropical and the sub-tropical regions. In Indonesia, the plant is cultivated in various conditions, such as in coastal areas and in the highlands. The peel and flesh parts of red dragon fruit have been known to have antioxidant properties due to its phenolic, flavonoids, ascorbic acid and betacyanin contents (Nurliyana et al., 2010; Luo et al., 2014). Many people have used this fruit, both as food and as food coloring. Furthermore, this fruit has also the potential to be developed as a nutraceutical supplement.

Some researchers have analyzed the benefits of red dragon fruit, both the flesh and the peel. The fruit flesh has been reported to be used for the treatment of diabetes, metabolic syndrome disease, preventing colitis and inflammation (Omidizadeh et al., 2014; Ramli et al., 2014). Furthermore, the peel has been reported to have the ability to reduce cholesterol level, triglycerides, and low-density lipids (LDL) in hyperlipidemic mice (Hernawati et al.,2018). Luo et al. (2014) found that red dragon fruit peel extract is toxic to cancer cells.

Preparation techniques are important for optimizing the benefits of a natural material. Azwanida (2015), Ramli et al. (2014), Garcia-Salas et al. (2010) reported that sample preparation and extraction techniques are important for maintaining compounds in a plant sample and determining the physiological properties of the extracted compounds. On the other hand, people are used to consuming the fruit in form of fresh fruit directly or juice. According to Phuong and Tuan (2016) dragon fruit juice provides additional value to the product and also increases its economic value. No studies have evaluated whether direct consumption or the juice of red dragon fruit has a significant effect if used as a pharmaceutical ingredient. In this study, we analyzed the effect of different preparation techniques of red dragon fruit peels and flesh on the viability of normal human fibroblasts.

\section{MATERIALS AND METHOD}

Materials

Plant material

The red dragon fruits used in this research were obtained from a local farmer in Bantul, Yogyakarta, Indonesia. The specimen of the plant was identified in the Laboratory of Plant Systematics, Faculty of Biology, Universitas Gadjah Mada, Yogyakarta by Abdul Razaq Chasani, S. Si., M. Si. Certificate number 01037/S.Yb/III/2017.

\section{Chemicals and reagents}

Ethanol (96\%) was purchased from Merck (Germany). Dulbecco's Modified Eagle Medium, Fetal Bovine Serum, Penicillin-Streptomycin, 0.25\% Trypsin-EDTA were purchased from Gibco (Canada). Ultrapure Thiazolyl blue was purchased from Bio Basic, Inc. (USA). Picric acid was purchased from Sigma-Aldrich, Inc. (USA).

\section{Methods \\ Sample preparation}

Red dragon fruits were first washed under running tap water and air-dried. Then, the fruits were peeled in order to separate the flesh from the peel. In this research, we used two preparation methods, i.e., maceration and non-maceration.

\section{Preparation via maceration}

This preparation method was based on optimization. In this preparation, both peel and flesh were used as samples. The peel and the flesh were separately ground using an electric blender prior to maceration in ethanol. The maceration processes for each sample used ethanol (96\%) as 
the solvent (ratio 1:10) for $48 \mathrm{~h}$ at room temperature, then the extract was evaporated using a vacuum rotary evaporator. Meanwhile, some peel was dried at $50^{\circ} \mathrm{C}$ for 4 days using an electric oven. The dried peel was subsequently pulverized into powder before it was macerated in ethanol. The maceration processes for this sample also used ethanol (96\%) as the solvent for $48 \mathrm{~h}$ at room temperature, then the filtrate was evaporated using a vacuum rotary evaporator. After ethanol was evaporated, the extracts of macerated samples (peel and flesh) were freeze-dried at $-20^{\circ} \mathrm{C}$ for 14 days.

\section{Preparation via non-maceration}

The preparation via non-maceration method was based on optimization. In the nonmaceration preparation, only the flesh of the fruits was used. The flesh was first divided into three equal parts. The first part of flesh was minced and pressed using a juice extractor to produce filtrates and pomaces. The filtrates and pomaces of the fruit were later freeze-dried at $-20^{\circ} \mathrm{C}$ for 14 days. The second part was blended using an electric blender prior to freeze-drying at $-20^{\circ} \mathrm{C}$ for 14 days. The last part was first dried in an electric oven at $50^{\circ} \mathrm{C}$ for 9 days before it was freezedried at $20^{\circ} \mathrm{C}$ for 14 days.

\section{Cell culture}

Normal human fibroblasts were obtained from Laboratory of Dermatology and Venereology Faculty of Medicine, Public Health and Nursing Universitas Gadjah Mada,Yogyakarta, Indonesia. Cell culture method was according to Jung et al. (2014) with some modifications. Fibroblasts $\left(5 \times 10^{3}\right.$ cells/well) were cultured in a 96 -well plate in DMEM plus $10 \%$ FBS and then incubated for 24 hours to obtain a monolayer cell culture. The fibroblast cultures then treated with various concentration of red dragon fruit samples $(500 ; 250 ; 125 ; 62,5 ; 31,25$; 15,$125 ; 7,8125 \mu \mathrm{g} / \mathrm{mL}$ ) then incubated for 24 hours in a $\mathrm{CO}_{2}$ incubator at $37^{0} \mathrm{C}$. The viability of fibroblasts was measured using the 3-(4,5-dimethylthiazol-2-yl)-2,5-diphenyltetrozolium bromide (MTT) assay.

\section{Cell viability test (MTT assay)}

This test is based on the changing color of MTT to formazan MTT by mitochondria in living cells. The methods were according to Jung et al. (2014) with some modifications. After incubation for 24 hours, the MTT reagent $(50 \mu 1,1 \mathrm{mg} / \mathrm{ml}$ in PBS) was added to each well and incubated for 4 hours. The supernatant was removed from the well, then added DMSO 200 $\mu \mathrm{L} /$ well. Absorbance was calculated using a microplate reader at $570 \mathrm{~nm}$. The viability of the cells was measured by the following equation:

$\%$ viability $=\left(\mathrm{A}_{\text {sample }}-\mathrm{A}_{\mathrm{C}(-)}\right)\left(\mathrm{A}_{\mathrm{C}(+)}-\mathrm{A}_{\mathrm{C}(-)}\right) \times 100 \%$

$\mathrm{A}_{\text {sample }}$ : Absorbance of a sample solution

$\mathrm{A}_{\mathrm{C}(-)} \quad$ : Absorbance of negative control (media)

$\mathrm{A}_{\mathrm{C}(+)} \quad$ : Absorbance of positive control (cells without UVB radiation)

\section{Data Analysis}

All experiments were performed in triplicate. The data were presented as a mean \pm standard error. Statistical significance was set at $\mathrm{p}=0.05$. The differences in cell viability between seven treatments were analyzed using one-way Anova and LSD tests. Data were analysed using SPSS Version 20. 


\section{RESULTS AND DISCUSSION}

Maceration is a common process done on natural products. In this study, the maceration process used ethanol as a solvent in order to extract the most pharmacological active compounds. The proposed purpose of the non-maceration methods was to accommodate the use of red dragon fruit by the local community

The data showed the ethanolic extract of red dragon fruit peel, both dried and blended, were toxic to the cells in a concentration-dependent manner. The higher concentration of peel extract, the lower percentage of cell viability observed (Figure. 1). Blended peel extract produced higher viability than dried peel extract. The highest viability was $69.42 \%$ and $51.5 \%$, respectively in blended peel and dried peel.

Luo et al., (2014) reported that the main content of red dragon fruit peel extract was $\beta$ amyrin $(15.87 \%), \alpha$-amyrin $(13.9 \%)$, octacosane $(12.2 \%), \gamma$-sitosterol $(9.35 \%)$, octadecane (6.27\%), 1-tetraconasol (5.19\%), stigmast-4-en-3-one (4.65\%), and campesterol (4.16\%). These compounds were reported for their cytotoxic properties on cancer cells, such as PC3 (human prostate cancer cell line) cells, Bcap-37 (human breast cancer cell line), and MGC 803 (human gastric cancer cell line). $\beta$-amyrin, $\gamma$-sitosterol, and stigmast-4-en-3-one inhibited the proliferation of those cancer cells. These three compounds may also play a role in reducing the viability of the normal fibroblast cells tested.

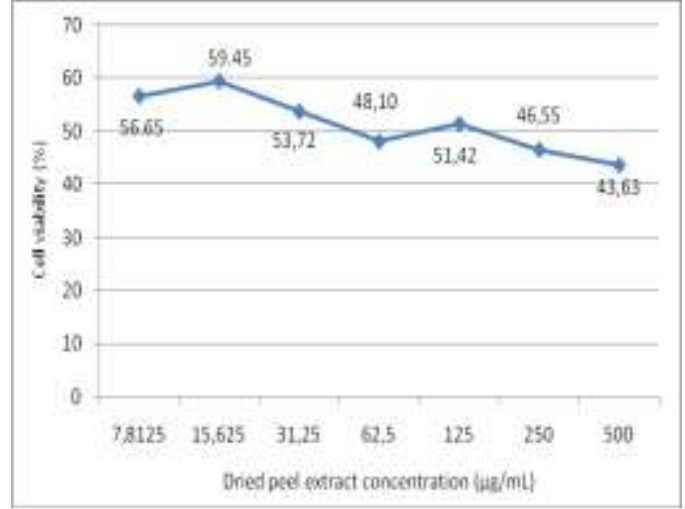

a

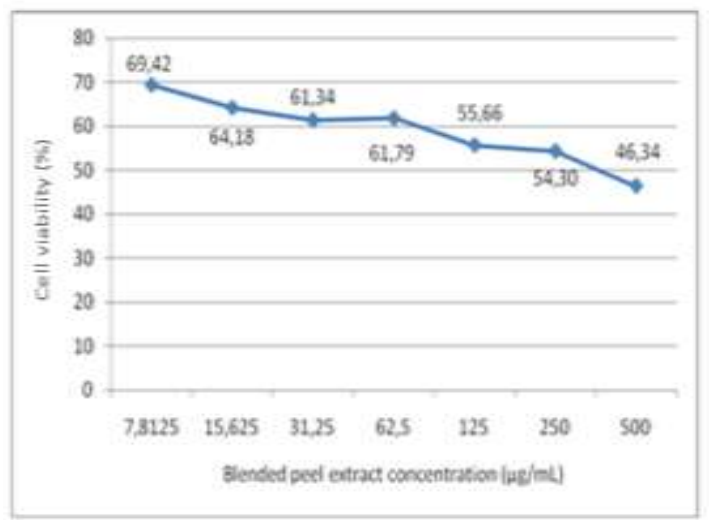

$\mathrm{b}$

Figure 1. The viability of fibroblasts treated with ethanolic extract of (a) dried peel, and (b) blended peel of red dragon fruit. Viability data were presented as mean $(n=3)$

In this study, both types of peel extract were macerated using ethanol, but in different sample preparation conditions, such as dried and fresh. The dried peel extract reduced cell viability more than the blended one. According to Azwanida (2015), drying is a method to keep the condition of plant samples. In this study, the process of drying the sample used an electrical oven. We assumed that the composition of toxic compounds in the dried peel sample was higher than the blended one because the drying process keep the cytotoxic content in the peel.

In another study, Larsson et al. (1999) showed that the composition of phenolic compounds produced from the hydrolysis process varies greatly depending on the source of the plant and its pre-treatment conditions. In this study, the pre-treatment conditions by drying were thought to produce more toxic compounds which reduce the viability of normal fibroblast cells.

$\mathrm{IC}_{50}$ values of dried peel extracts and blended peel extracts were $55.38 \pm 3.85 \mu \mathrm{g} / \mathrm{mL}$ and $>500 \mu \mathrm{g} / \mathrm{mL}$ respectively (Table I). The dried peel extract was much more toxic than blended peel extract. Research by Luo et al. (2014) found that red dragon fruit peel extracted by carbon dioxide supercritical method has cytotoxic properties on PC3 (human prostate cancer cell line) cells, 
Bcap-37 (human breast cancer cell line), and MGC 803 (human gastric cancer cell line) with $\mathrm{IC}_{50}$ values ranging from $0.61-0.73 \mathrm{mg} \mathrm{mL}(610-730 \mu \mathrm{g} / \mathrm{mL})$.

Various preparation methods of the flesh part of the red dragon fruit showed a different effect on the viability of human normal fibroblasts. No concentration-dependent manner was observed in the cytotoxicity effect of the ethanolic extract of blended flesh (Figure 2a). The lowest viability of cells occurred in the lowest concentration $(7.8125 \mu \mathrm{g} / \mathrm{mL}) . \mathrm{IC}_{50}$ value of this sample can't be determined because the viability value at various concentration didn't linear.

Table I. $\mathrm{IC}_{50}$ values of various sample treatments of red dragon fruit's peel and flesh

\begin{tabular}{lc}
\hline \multicolumn{1}{c}{ Treatments } & IC $_{\mathbf{5 0}}(\boldsymbol{\mu g} / \mathbf{m L})$ \\
\hline Maceration & \\
Dried peel & $55.38 \pm 3.85$ \\
Blended peel & $>500$ \\
Blended flesh & $\mathrm{ND}$ \\
Non-maceration & \\
Blended flesh & $\mathrm{ND}$ \\
Dried flesh & $>500$ \\
Pomace of pressed flesh & $\mathrm{ND}$ \\
Filtrate of pressed flesh & $>500$ \\
\hline
\end{tabular}

*Maceration using ethanol, ND : Can not be determined

Various preparation methods of the flesh part of the red dragon fruit showed a different effect on the viability of human normal fibroblasts. No concentration-dependent manner was observed in the cytotoxicity effect of the ethanolic extract of blended flesh (Figure 2a). The lowest viability of cells occurred in the lowest concentration $(7.8125 \mu \mathrm{g} / \mathrm{mL}) . \mathrm{IC}_{50}$ value of this sample can't be determined because the viability value at various concentration didn't linear.

There was a tendency of decreasing viability in dried flesh treatment cells (Figure 2b). At the highest concentration of extract $(500 \mu \mathrm{g} / \mathrm{mL})$, only $41.9 \%$ survived. There was an indication that the dried flesh was toxic to the cells.

Blended flesh of fresh red dragon fruit at various concentrations has no significant effect on cell viability (Figure. $2 \mathrm{c}$ ). Cell viability in all concentrations was more than $80 \%$, even at $125 \mu \mathrm{g} /$ $\mathrm{mL}$ the viability exceeded the control group $(105 \%)$. Based on these results it can be concluded that blended flesh of red dragon fruit has the potential to increase cell viability. 


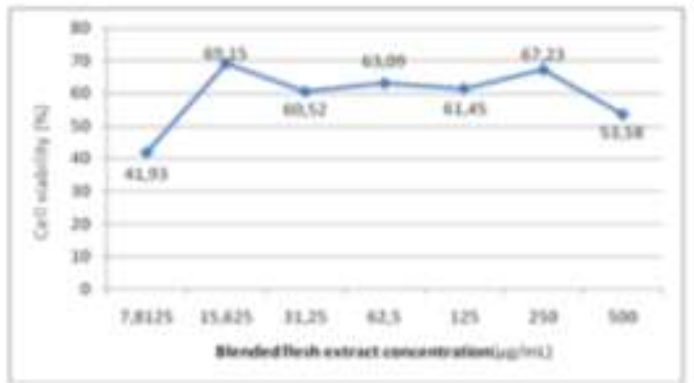

(a)

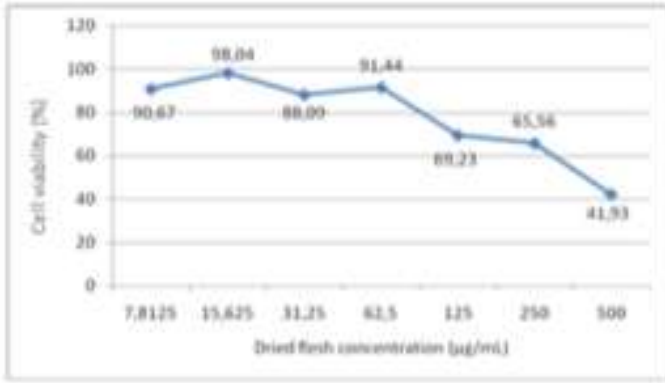

(b)

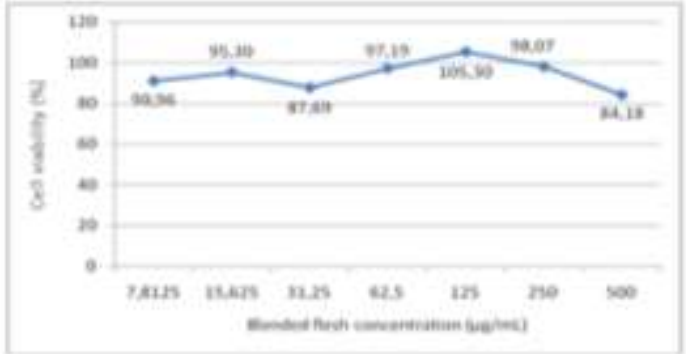

(c)

Figure 2. The viability of fibroblasts treated with (a) ethanolic extract of blended flesh, (b) dried flesh, and (c) blended flesh. Viability data were presented as mean $(n=3)$

A similar trend was showed by the pomace of pressed flesh and filtrate of pressed flesh. All sample concentrations had no significant effect on fibroblast viability compared to controls without red dragon fruit treatment (Figure $3 \mathrm{a}$ and $3 \mathrm{~b}$ ). Cell viability in all concentrations was above $70 \%$. The pomace of pressed flesh at $125 \mu \mathrm{g} / \mathrm{mL}$ produced the highest cell viability (98\%) and the filtrate of pressed flesh at $31.25 \mu \mathrm{g} / \mathrm{mL}$ cells showed the highest viability $(96 \% \pm 22 \%)$.

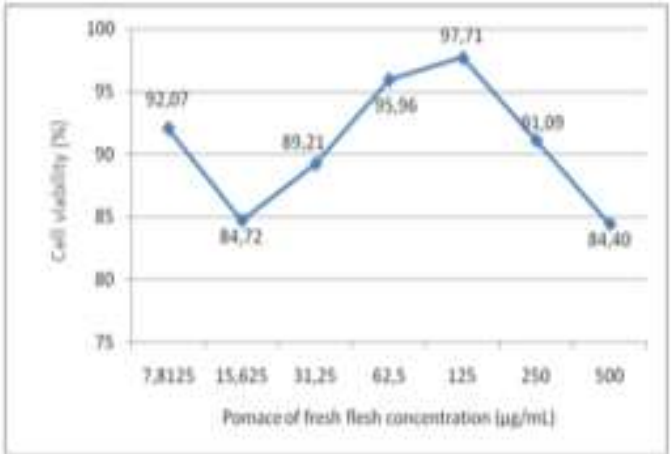

(a)

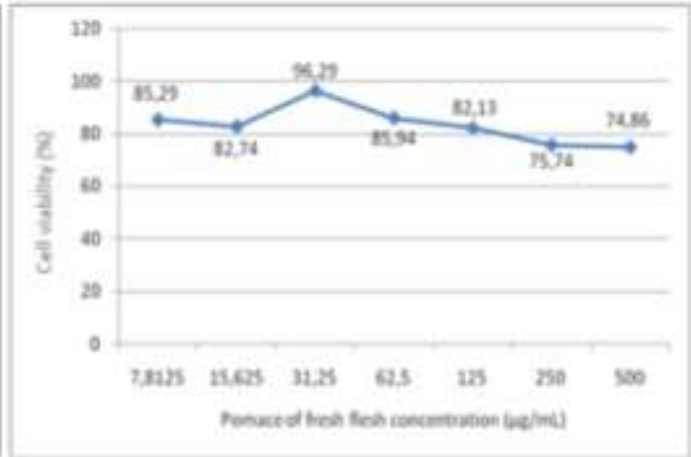

(b)

Figure 3. The viability of fibroblasts treated with (a) pomace of pressed flesh, and (b) filtrate of pressed flesh. Viability data were presented as mean $(n=3)$

Different preparation treatments of red dragon fruit flesh showed that the flesh had no toxic effect on the human normal fibroblasts. Hor et al. (2012) reported that methanolic extract of red dragon fruit flesh did not have acute or chronic toxicity to mice. No signs of damage to vital organs such as the liver, kidneys, and lungs were observed.This is consistent with the results in this study.

In this study, it is known that fruit peel tends to be toxic to the cells. The results indicated the potential of red dragon fruit peel to be used as an anti-cancer agent. In another study, 
Nurmahani et al., (2012) obtained the potential of red dragon fruit peel extracts as an antibacterial agent against nine types of pathogenic bacteria tested. These results give valuable information about the promising application from the peel.

The fruit flesh does not have a significant negative effect. Blended fruit flesh can produce higher cell viability than untreated controls. Preparation without maceration has a better effect on cell viability than the maceration one. These findings are the basis for utilizing red dragon fruit flesh in further research as a natural product to protect cells from environmental stress.

Overall, it was found that red dragon fruit peel and flesh prepared with various preparation methods affected the viability of human normal fibroblast. The preparation method affects the phytochemical content of the peel and flesh of the red dragon fruit. This finding will have implications for the physiological activities and functions of those parts.

\section{CONCLUSION}

This study concluded that various preparation techniques of red dragon fruit peels and flesh resulted in different effects on the viability of normal human fibroblasts. The dried and blended peel were toxic to the cells in a concentration-dependent manner. Different preparation treatments of red dragon fruit flesh showed that the flesh caused no toxic effect on the human normal fibroblasts in the concentrations tested. Therefore, it can be concluded that the flesh is relatively safer to normal cells than the peel extracts.

\section{ACKNOWLEDGEMENT}

This research was funded by Universitas Ahmad Dahlan through the Scheme of Competitive Research Grant 2018 (No PHB-025/SP3/LPP-UAD/IV/2018).

\section{REFERENCES}

Azwanida, N., 2015, A Review on the Extraction Methods Use in Medicinal Plants, Principle, Strength and Limitation. Medicinal and Aromatic Plants 4(3): 3-8.

Garcia-Salas, P., Morales-Soto A., Segura-Carretero A., Fernández-Gutiérrez A. 2010, PhenolicCompound-Extraction Systems for Fruit and Vegetable Samples, Molecules 15: 88138826.

Hernawati, Setiawan, N. A., Shintawati, R., and Priyandoko, D., 2018, The Role Dragon Fruit Peel (Hylocereus polyrhizus) to Improvement Blood Lipid Levels of Hyperlipidemia Male Mice. Journal of Physics: Conference Series: 1-5.

Hor, S. Y., Ahmad M., Farsi E., Yam M. F., Hashim M. A., Lim C. P., Sadikun A., Asmawi M. Z., 2012, Safety assessment of methanol extract of red dragon fruit (Hylocereus polyrhizus): Acute and subchronic toxicity studies. Regulatory Toxicology And Pharmacology, 63: 106-114.

Jung, H.-Y., Jae-Cheon S., Seon-Min P., Na-Ri K., Wonjung K., Bo-Hwa C. 2014, Pinus densiflora extract protects human skin fibroblasts against UVB-induced photoaging by inhibiting the expression of MMPs and increasing type I procollagen expression. Toxicology Reports 1: 658-666.

Larsson, S., Eva P., Barbel H., Charlotte T., Kerstin S., Guido Z., Nils-Olof N. 1999, The generation of fermentation inhibitors during dilute acid hydrolysis of softwood, Enzyme and Microbial Technology, 24(3-4): 151-159.

Luo, H., Cai Y., Peng Z., Liu T., Yang S., 2014, Chemical composition and in vitro evaluation of the cytotoxic and antioxidant activities of supercritical carbon dioxide extracts of pitaya (dragon fruit) peel. Chem Cent. J. 8: 1-7.

Nurliyana, R., Syed Z. I., Mustapha S. K., Aisyah M. R., and Kamarul R. K., 2010, Antioxidant study of pulps and peels of dragon fruits: A comparative study. International Food Research Journal. 17: 367-375.

Nurmahani, M. M. A., Osman A., Abdul H. F., Mohamad G., and M.S. Pak Dek., 2012, 
Antibacterial activity of Hylocereus polyrhizus and Hylocereus undatus peel extract. International Food Research Journal. 19 (1): 77-84.

Omidizadeh, A., Rokiah M. Y., Shahin R., Amin I., Mohd Z. A. B., and Alaa E. A. B., 2014, Anti-diabetic activity of red pitaya (Hylocereus polyrhizus) fruit. RSC Adv. 4(108): 6297862986.

Phuong, N. M. and Tuan, Q., 2016, Application of Hydrolytic Enzymes for Improvement of Red Dragon Fruit Juice Processing. Department of Food Technology, International University Viet Nam National University HCM city Quater 6, Ho Chi Minh city, Viet Nam 4(1): 1-4.

Ramli, N. S., Ismail, P. and Rahmat, A., 2014, Influence of conventional and ultrasonic-assisted extraction on phenolic contents, betacyanin contents, and antioxidant capacity of red dragon fruit (Hylocereus polyrhizus). Scientific World Journal 1-7. 